\title{
THE EFFECTIVENESS OF ORAL SUPEROXIDE DISMUTASE (SOD) ON TOTAL ANTIOXIDANT STATUS, TRANSEPIDERMAL WATER LOSS (TEWL) AND SEBUM CONCENTRATION IN PHOTO AGING SKIN
}

\author{
Khairuddin Djawad https://orcid.org/0000-0002-2322-7633 \\ Dewi Anggraini https://orcid.org/0000-0003-1086-8615 \\ Medical Faculty, Hasanuddin University, Makassar, Indonesia \\ duddindjawad@gmail.com
}

\begin{abstract}
Relevance. Aging is a progressive process of decrease in organs functions and capacity, including the skin. Photoaging is extrinsic aging mainly occur due to ultraviolet (UV) exposure. The effectiveness of oral SOD for premature aging is still not yet known.

Objective: we aimed to evaluate the effectiveness of this antioxidant on total antioxidant status (TAS), skin hydration (TEWL), and sebum concentration in premature skin aging.

Methods. This study is a clinical trial research design with one group pre-post test. All subjects who were exposed to UV for approximately 3-4 hours. All subjects signed an informed consent and were interviewed accordingly. Photoaging was diagnosed clinically by three dermatologists according to Glogau type II classification such as dynamic wrinkles, palpable keratosis, visible lentigo senilis, and smiley line. SOD 250 IU was given to all subjects twice daily for 60 days. Laboratory examinations such as TAS, TEWL, and sebum concentration were done pre and post-intervention.

Results. A total of 25 subjects, Fitzpatrick skin type 4 were included in this study. There were 14 males and 11 females with 20 subjects age 30-40 years old and 5 subjects age 25-29 years old. Fourteen (56\%) out of 18 subjects from low TAS group have normal TAS post-treatment with SOD. McNemar test showed a significant increase in TAS value pre and post-treatment with SOD ( $\mathrm{p}<0.05$ ). TEWL measurement on cheek showed 9 out of 10 subjects from the strained group have normal TEWL post-treatment, while all 3 subjects from the critical group have normal TEWL value. Measurement on the forehead showed 7 subjects from the strained group have a normal TEWL. Sebumeter on the forehead showed 17 subjects from dry skin group 14 (56\%) subjects have normal skin, 1 (4\%) subject becomes oily, and 2 subjects remains dry post-treatment with SOD for 60 days. All subjects with dry skin on U zone become normal skin post-treatment.
\end{abstract}

Conclusion. SOD significantly increased TAS value, decreased TEWL, and improvement of skin dryness post-treatment with SOD for 60 days.

Keywords: Superoxide Dismutase, TAS, TEWL, Sebum

Relevance. Aging is a progressive process of decrease in organs functions and capacity, including the skin [1]. The aging process was divided into intrinsic and extrinsic pathways. Intrinsic aging is a chronologically aging process, associated with genetic factors, while extrinsic aging is environmentally mediated. Extrinsic aging which is also referred to photoaging, result in skin damaged due to ultraviolet (UV) exposure [2]. Photo damaged skin has acanthotic epidermis and more profound decrease in Langerhans cell compared to intrinsic aging. Differences in UV defense mechanism between white skin and darker skin types provides differences in clinical manifestations. Most common clinical signs in Asian skin are solar lentigines and mottled pigmentation, while wrinkles only occur in sixth decade and have intense sun exposure [1]. Histopathologically, photoaged skin has a significant increase in fiber bundles spaces, thinning of fibers, and increased disorganization of fiber proteins [3-5].

One of the main contributing factors in the cellular aging process is the overproduction of Reactive Oxygen Species (ROS) and resulted in oxidative stress [6]. ROS is produced during normal intracellular metabolism and has an important role in cell differentiation, proliferation, and host defense response, but UV radiation is also known as a potent initiator of ROS productions in the skin [7-8]. ROS can be divided into oxygen molecules that have unpaired electron (includes superoxide anion radicals, hydroxyl radicals, lipid peroxyl radicals, nitric oxide radicals) and in an excited state (singlet oxygen). Superoxide anion radicals can be spontaneously converted to hydrogen peroxide or metabolized by superoxide dismutase (SOD) [8].

Enzymatic and non-enzymatic antioxidants act systemically to scavenge free radicals. The enzymatic antioxidant is the main defense mechanism against ROS in vitro and consists of superoxide dismutase (SOD), catalase (CAT), glutathione peroxidase (GPx), and glutathione reductase (GR). Two main types of SOD are CuZnSOD (SOD1) and MnSOD (SOD2) $[9,10]$. The non-enzymatic antioxidant (vitamin C, E) as the second line defense system, not only provide direct protection against oxidative damage, but it also enhances the endogenous enzymatic antioxidant synergistically [11]. SOD is a substantial antioxidant defense against oxidative stress which has anti-inflammatory properties and also prevents 
precancerous cell changes. It is commonly used in as anti-aging and antioxidant that can reduce wrinkles, fine lines, and age spots [12, 13].

Stimulation of sebaceous gland function due to oxidative stress induced by UV radiation will subsequently increase sebum secretion. It might be due to increased levels of oxidized lipids, triglyceride hydroperoxides, and cholesterol hydroperoxides [14].

The total antioxidant status examination is regarded as one of the parameters used to evaluate the negative effect of antioxidants, which is considered as an oxidative stress indicator. Giving antioxidant in low total antioxidant status can reduce the negative impact of free radicals [15]. The antioxidant such as SOD can stimulate the production of endogenous antioxidants, increase antioxidant status, and prevent disease manifestation due to free radicals.

Objective: The effectiveness of oral SOD for premature aging is still not yet known, thus we aimed to evaluate the effectiveness of this antioxidant on total antioxidant status (TAS), skin hydration (TEWL), and sebum concentration in premature skin aging.

\section{METHODS}

Study design. This study is a clinical trial research design with one group pre-post test.

\begin{tabular}{|l|}
\hline Premature aging \\
Glogau grade II \\
(appearance of smile lines, \\
early age spots, skin pores \\
more prominent,
\end{tabular}

early age spots, skin pores

more prominent,

\section{Premature aging}

Glogau grade II

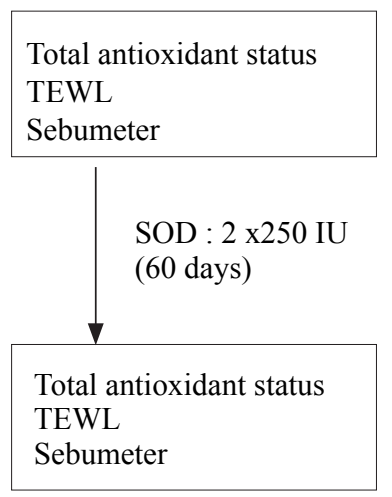

Fig. 1. Study Flow Chart

Subject characteristic. The study population was all patient with premature aging consulted at Outpatient Department, Department of Dermatology and Venereology, Dr. Wahidin Sudirohusodo Hospital, Cosmetic Subdivision, Makassar. Inclusion criteria were all patient diagnosed with photoaging clinically with a good general condition, neither taking antioxidant (vitamin $\mathrm{C}, \mathrm{E}, \beta$-carotenoid, Lycopene, Leucoselect phytosome, etc), having dermatitis or skin inflammation on the face and surroundings. Patients with chronic disease, pregnant, on maintenance with any cosmetics, rejuvenation treatment with topical antioxidant, topical retinoid, or chemical peeling will be excluded from this study.
Sample size. Total sample size 25 subjects and sampling was done in a proportional manner where all the subjects were sorted according to an initial visit at OPD.

Study Protocol. All subjects signed the informed consent and were interviewed accordingly. They filled in a questionnaire and were examined clinically by three dermatologists for signs of premature aging according to Glogau type II classification such as wrinkles in motion, palpable keratosis, visible lentigo senilis, and smiley line. SOD $250 \mathrm{IU}$ was given to all subjects twice daily for 60 days. Laboratory examinations such as TAS, TEWL, and sebum concentration were done pre and post-intervention:

1. Evaluation of TAS. Venipuncture was done in each subject to measure the total antioxidant serum (TAS) level pre and post-treatment. The TAS level examination was done using ELISA with human total antioxidant capacity (T-AOC) kit (Bioassay Technology Laboratory) following the instruction from the manufacturer.

2. TEWL measurement. Interpretation of TEWL measurement seen in Table 1, according to the protocol in all samples using Tewameter/ Cornoemeter 350 (TC350) made by Courage \& Khazaka electronic GmbH, Jerman year 1997.

Table 1

\section{Interpretation using Tewameter}

\begin{tabular}{|c|c|}
\hline TEWL values $\mathbf{g} / \mathbf{h} / \mathbf{m}^{\mathbf{2}}$ & Interpretation \\
\hline $0-10$ & Very healthy condition \\
\hline $10-15$ & Healthy condition \\
\hline $15-25$ & Normal condition \\
\hline $25-30$ & Strained condition \\
\hline$>30$ & Critical condition \\
\hline
\end{tabular}

Sebum concentration. Interpretation of sebum concentration seen in the Table 2, according to protocol in all samples using SebumeterÒ SM 815 made by Courage \& Khazaka electronic GmbH, Jerman year 2003.

Table 2

Interpretation using Sebumeter

\begin{tabular}{|c|c|c|c|}
\hline Skin type & $\begin{array}{c}\text { Whole face } \\
\text { (MSFE) }\end{array}$ & $\begin{array}{c}\text { T zone (forehead, } \\
\text { nose, } \text { chin) }\end{array}$ & $\begin{array}{c}\text { U zone } \\
\text { (cheek) }\end{array}$ \\
\hline Dry & $<88$ & $<100$ & $<70$ \\
\hline Normal & $88-204$ & $100-220$ & $70-180$ \\
\hline Oily & $>204$ & $>220$ & $>180$ \\
\hline
\end{tabular}

Data analysis. Collected data were analyzed using SPSS version 11.5. McNemar test was being used for the hypothesis to compare antioxidant value pre and post-treatment. Significant value if $\mathrm{p}<0.05$. 


\section{RESULTS AND DISCUSSION}

Subject characteristics. A total of 25 subjects, Fitzpatrick skin type 4 were included in this study. There were 14 males and 11 females with 20 subjects age 30-40 years old and 5 subjects age 25-29 years old. All patients have to work outside for approximately 3-4 hours of UV exposure.

On physical examination, all subjects have a dynamic wrinkle, 23 subjects have seborrheic keratosis and smiley line, 5 subjects have lentigo senilis. Eleven (44\%) subjects not a smoker, and from 14 smokers, $8(32 \%)$ subjects have 1 pack a week and 6 (24\%) subjects have $1-2$ packs per day.

Total antioxidant status (TAS). TAS value pre-treatment with SOD was low in 18 (72\%) subjects and normal in $7(28 \%)$ subjects. It was found that $14(56 \%)$ out of 18 subjects from low TAS group have normal TAS post-treatment with SOD. McNemar test showed a significant increase in TAS value pre and post-treatment with SOD $(\mathrm{p}<0.05)$. McNemar test $\mathrm{p}$-value $=$ 0,000 .

Table 3

Mean value on TAS, TEWL, and sebum concentration pre and post-treatment with SOD in premature aging subjects

\begin{tabular}{|c|c|c|c|}
\hline \multirow{2}{*}{ Measurement } & \multirow{2}{*}{$\mathbf{N}$} & \multicolumn{2}{|c|}{ Mean \pm SD } \\
\cline { 3 - 4 } & & Pre-treatment & Post-treatment \\
\hline TAS & 25 & $1,187 \pm 0,169$ & $1,545 \pm 0,174$ \\
\hline TEWL cheek & 25 & $24,82 \pm 4,489$ & $17,56 \pm 2,662$ \\
\hline TEWL forehead & 25 & $24,52 \pm 4,869$ & $18,54 \pm 3,214$ \\
\hline Sebumeter cheek & 25 & $40,80 \pm 19,177$ & $77,76 \pm 23,392$ \\
\hline Sebumeter chin & 25 & $56,96 \pm 24,337$ & $110,52 \pm 37,734$ \\
\hline
\end{tabular}

paired T test $(p=0,000)$

Table 4

TEWL measurement on the cheek and forehead pre and post-treatment with SOD

\begin{tabular}{|c|c|c|c|c|c|}
\hline \multirow{2}{*}{\multicolumn{2}{|c|}{$\begin{array}{c}\text { TEWL } \\
\text { Pre-treatment } \\
\text { Healthy N (\%) }\end{array}$}} & \multicolumn{3}{|c|}{ TEWL post-treatment } & \multirow{3}{*}{$\begin{array}{c}\text { Total } \\
\text { N (\%) } \\
12(48)\end{array}$} \\
\hline & & \multirow{2}{*}{$\begin{array}{c}\begin{array}{c}\text { Normal } \\
\text { N (\%) }\end{array} \\
3(12)\end{array}$} & \multirow{2}{*}{$\begin{array}{c}\text { Strained } \\
\text { N (\%) } \\
9(36)\end{array}$} & \multirow[b]{2}{*}{$0(0)$} & \\
\hline \multirow{4}{*}{ Cheek } & Normal & & & & \\
\hline & Strained & $1(4)$ & $9(36)$ & $0(0)$ & $10(40)$ \\
\hline & Critical & $0(0)$ & $3(12)$ & $0(0)$ & $3(12)$ \\
\hline & Total & $4(16)$ & $21(84)$ & $0(0)$ & $25(100)$ \\
\hline \multirow{4}{*}{ Forehead } & Normal & $3(12)$ & $11(44)$ & $0(0)$ & $14(56)$ \\
\hline & Strained & $0(0)$ & $7(28)$ & $1(4)$ & $8(32)$ \\
\hline & Critical & $1(4)$ & $1(4)$ & $1(4)$ & $3(12)$ \\
\hline & Total & $4(16)$ & $19(76)$ & $2(8)$ & $25(100)$ \\
\hline
\end{tabular}

Transepidermal water loss (TEWL). TEWL measurement on cheek showed 9 out of 10 subjects from the strained group have normal TEWL post-treatment, while all 3 subjects from the critical group have normal TEWL value. Measurement on the forehead showed 7 subjects from the strained group have a normal TEWL, while 3 subjects from the critical group have a healthy TEWL in 1 subject, have normal value in 1 subject and 1 subject remains in critical value (Table 4).

Sebumeter. Sebumeter on forehead showed 17 subjects from dry skin group $14(56 \%)$ subjects have normal skin post-treatment with SOD for 60 days. On U zone (cheek), all subjects have dry skin and 18 (72\%) of them becoming normal skin.

Table 5

Sebumeter pre- and post-treatment with SOD

\begin{tabular}{|c|c|c|c|c|c|}
\hline \multirow{2}{*}{\multicolumn{2}{|c|}{$\begin{array}{c}\text { Sebumeter pre-treatment } \\
\text { Dry N (\%) }\end{array}$}} & \multicolumn{3}{|c|}{ Sebumeter post-treatment } & \multirow{3}{*}{$\begin{array}{c}\text { Total } \\
\text { N (\%) } \\
17(68)\end{array}$} \\
\hline & & \multirow{2}{*}{$\begin{array}{c}\begin{array}{c}\text { Normal } \\
\text { N (\%) }\end{array} \\
2(8)\end{array}$} & \multirow{2}{*}{$\begin{array}{c}\begin{array}{c}\text { Oily } \\
\text { N (\%) }\end{array} \\
14(56)\end{array}$} & \multirow[b]{2}{*}{$1(4)$} & \\
\hline \multirow{3}{*}{$\begin{array}{l}\text { T zone / } \\
\text { forehead }\end{array}$} & Dry N (\%) & & & & \\
\hline & Normal N (\%) & $0(0)$ & $8(32)$ & $0(0)$ & $8(32)$ \\
\hline & Total N (\%) & $2(8)$ & $22(88)$ & $1(4)$ & $25(100)$ \\
\hline \multirow{3}{*}{$\begin{array}{c}\text { U zone / } \\
\text { cheek }\end{array}$} & Dry N (\%) & $7(28)$ & $18(72)$ & $0(0)$ & $25(100)$ \\
\hline & Normal N (\%) & $0(0)$ & $0(0)$ & $0(0)$ & $0(0)$ \\
\hline & Total N (\%) & $7(28)$ & $18(72)$ & $0(0)$ & $25(100)$ \\
\hline
\end{tabular}

Dverse events. There were no adverse events found in this study.

Ultraviolet radiation can induce matrix metalloproteinases and be sustained with multiple exposures [16]. Matrix metalloproteinases are proteolytic enzymes that degrade proteins in connective tissue particularly collagen and elastin. They are important for matrix remodeling during wound healing [17]. It is also considered as the primary mediators of connective tissue damage in photodamaged skin [16]. Photoaging affects all three layers of the epidermis, but changes in the dermal layer seem to be the primary process in nature, while epidermal changes are often secondary [18].

A total of 25 subjects included in this study with more than $80 \%$ of them age $30-40$ years old. Excessive UV exposure can cause severe photoaging as early as the second decade of life [19]. Photoaging signs are more evident in most women on 2nd-3rd decade of life [20]. Other literature stated that extrinsic aging begins in the second decade [21].

Skin as the first line barrier from the surrounding environment, which can produce oxidative stress [6]. Environmental factors such as sun radiation (ultraviolet radiation, visible light, and infrared radiation), air 
pollution, tobacco smoke, cosmetic products are known contributes to skin aging by the formation of oxidative stress [18]. UVR has been considered as a potential contributor for free radicals. Exposure to the skin causing absorption of photons by natural chromophores, which includes porphyrins, flavins, bilirubin, urocanic acid, vitamin $\mathrm{K}$ and B6 derivatives, and even DNA. On excitation, chromophores will be having molecular changes, thus becoming electron donors. Reaction with other electron form free radicals that finally result in oxidative stress $[6,22]$. Free radicals can be formed naturally from normal cell metabolism thus causing oxidative stress [23]. Oxidative stress affects skin aging through several mechanisms, includes decreasing proteasome function [24], DNA damage [25], replicative senescence in human dermal fibroblast and melanocytes [26], shortening of the telomeres [6]. The skin has a defense mechanism against oxidative stress with an antioxidant enzyme produced within the body, such as SOD, catalase, GR, GSH-Px, etc. [27].

Collagen is an important component of the skin. Loss of collagen will promote sagging, signs of aging, and decrease skin hydration. Collagen fragment products promote a further increase of ROS in dermal fibroblasts [28]. A decrease in collagen can activate receptormediated signaling pathways of various cytokines and growth factors within the keratinocytes and dermal fibroblasts. Induction of c-Jun will form a component of activator protein 1 (AP-1) and nuclear factor $\kappa \mathrm{B}(\mathrm{nF}-$ $\kappa \mathrm{B})[29,30]$. The induction of these proteins leads to decreased collagen synthesis and increased collagen breakdown through the activation of metalloproteinases (MMPs), collagenases, and gelatinase. Failure of dermis repair result in solar elastosis histopathologically and lead to visible signs of photo-aging [6].

ROS accumulation plays an important role in photoaging where antioxidant enzyme significantly declines on the corneum layer and increase the concentration of protein oxidation in the upper dermis [31]. Our study showed SOD increased TAS value and sebum concentration while decreasing in TEWL.

Superoxide dismutases are a group of metalloenzymes included as enzymatic antioxidants against ROSmediated injury [32]. SODs can be classified into the following: Copper-Zinc-SOD (Cu, Zn-SOD), Iron SOD (Fe-SOD), Manganese SOD (Mn-SOD), and Nickel SOD $[33,34]$, but two main types are CuZnSOD (SOD1) and MnSOD (SOD2) [9, 10]. Natural SOD within the body will decrease with age hence they are more susceptible to oxidative stress-mediated diseases [35].

SOD has been widely used in cosmetic products as anti-aging and antioxidant because it can reduce free radical skin damage and also protect against UV radiation, faster wound healing, and reduce another skin aging [13]. SOD synthetic offers a potential treatment due to their smaller size, longer half-life, and have similar activity with natural SOD by converting O2- into $\mathrm{H} 2 \mathrm{O} 2$ then further converted into water by catalase [36].

SOD as the primary antioxidant is first line defense mechanism against oxidative stress. SOD has high catalytic rate and can renew itself constantly, while secondary antioxidants are quickly exhausted and no possibility of renewal [37]. The antioxidant defense mechanism of the skin has been reported in many studies where a single exposure to UVB can induce disruption of antioxidant defense mechanism and SOD activity in the epidermal layer [38, 39]. Administration of antioxidant supplementation in low endogenous antioxidant after UV exposure can prevent oxidative stress-mediated skin damage [40].

Nicotine and other substances in tobacco have known to cause unfavourable skin changes or even skin cancer. Tobacco can accelerate skin aging natural process that can be observed in 40 years smoker skin which is similar with 70-year-old non-smoker skin. Skin damage due to tobacco is irreversible and further damage can only be reduced by smoking cessation [41].

Yin et al studied the correlation between tobacco smoking and skin aging. They investigated the alterations of collagen, matrix metalloproteinases (MMPs) and tissue inhibitors of metalloproteinases (TIMPs) in human fibroblast treated with tobacco smoke extract. Human fibroblasts exposed to UVA1 radiation were used as positive controls. Collagen synthesis was found reduced by $40.1 \%$ with $25 \mathrm{micro} / \mathrm{ml}$ of tobacco smoke extract. The expression of MMP-1 and MMP-3 mRNA were significantly increased with tobacco smoke extract or UVA1 radiation. Antioxidants such as sodium azide, L-ascorbic acid and Trolox can prevent alteration of MMP1 induced either by tobacco or UVA1 [42]. Rocquet et al found that smoking can increase MMP-1 activity on the skin causing an imbalance of MMP-1 and TIMP-1, which plays an important role in skin aging [31].

Miyachi et al conducted studies on mice and found that UVB contributes to the lower SOD activity in the skin. In human, a decrease in SOD activity was also found in fibroblasts and catalase activity after UVB. The imbalance between oxidants and antioxidants will cause continuous and increase in cumulative oxidative stress. Environmental factor such as pollutants can accelerate the aging process, and exogenous antioxidants reduce the toxicity of ROS [43]. Antioxidants can be considered as a strategy against excessive ROS and subsequently lower the incidence of photoaging [27].

TEWL has been known to be increased during skin barrier disruption, which can be caused by chemical, microorganisms, physical trauma, and UV radiation [44]. TEWL has commonly used a parameter to assessed photoprotective effect on the skin, especially epidermal barrier function disruption due to UV radiation [45]. Wang et al investigated the effect of chronic UV exposure on skin barrier function and photoaging. They 
compared TEWL of UV-exposed skin areas with UVnonexposed skin areas in elderly ( $>50$ years old). There were increased TEWL levels on UV-exposed skin but there was not statistically different $(\mathrm{p}>0.05)$ compared to UV-nonexposed skin areas. This result might be due to subjects were from the geriatric group with relatively higher TEWL. In contrast to our study, there was a significant improvement of TEWL in younger age groups after SOD administration [46]. Recently, there were not yet available studies of antioxidants in decreasing TEWL and increasing sebum concentration.

UV radiation especially UVA have deeper penetration and damage sebaceous glands. An experimental study by Leyden et al in UV induced photoaged hairless mice showed marked sebaceous glands hyperplasia. This result is similar to study by Di Cerbo et al which significant increase in sebum concentration occurred in patients with photoaging $(p<0.001)$ [47]. In contrast, our study showed an improvement of skin dryness seen in all subjects with dry skin has normal skin after 60 days of SOD. Study by Tokudome et al showed a decrease in intracellular lipid content and decreased in proportion to the number of differentiated cells. Antioxidants inhibit sebaceous lipid production by suppressing differentiation of sebocyte [48].

In terms of adverse events, all subjects had no adverse events after 2 months of taking SOD 250 IU twice daily for 60 days. A similar result was also found in a study by Garcia-Gonzales et al. [49].

\section{CONCLUSION}

There were a significant increase in TAS value, decrease in TEWL, and improvement of skin dryness after taking oral SOD for 2 months.

\section{REFERENCES}

1. Yaar M, Gilchrest B. Aging of Skin. In: Goldsmith L, Katz S, Gilchrest B, Paller A, Leffell D, Wolff K, editors. Fitzpatrick Dermatology in General Medicine. 1. 8th ed. New York: McGraw-Hill; 2012. p. 1213-26. View in: URL: https:/accessmedicine.mhmedical.com/ content. aspx ?bookid $=392 \&$ sectionid $=41138823$

2. Rinnerthaler M, Bischof J, Streubel MK, Trost A, Richter K. Oxidative stress in aging human skin. Biomolecules. 2015;5(2):545-89. DOI: 10.3390/biom5020545 View at: Publisher Site: https://www.mdpi. com/2218-273X/5/2/545

PubMed: https://pubmed.ncbi.nlm.nih.gov/25906193/ PubMed Central: https://www.ncbi.nlm.nih.gov/pmc/ articles/PMC4496685/

3. Mera S, Lovell C, Jones RR, Davies J. Elastic fibres in normal and sun-damaged skin: an immunohistochemical study. British Journal of Dermatology. 1987;117(1):21-7. DOI: 10.1111/j.1365-2133.1987. tb04086.x

View at: Publisher Site: https://onlinelibrary.wiley.com/ doi/abs/10.1111/j.1365-2133.1987.tb04086.x
PubMed: https://pubmed.ncbi.nlm.nih.gov/3651333/

4. Warren R, Gartstein V, Kligman AM, Montagna W, Allendorf RA, Ridder GM. Age, sunlight, and facial skin: a histologic and quantitative study. Journal of the American Academy of Dermatology. 1991;25(5):75160. DOI: $10.1016 / \mathrm{s} 0190-9622(08) 80964-4$

View at: Publisher Site: https://www.jaad.org/article/ S0190-9622(08)80964-4/pdf

PubMed: https://pubmed.ncbi.nlm.nih.gov/1802896/

Europe PMC: https://europepmc.org/article/ $\mathrm{med} / 1802896$

5. Kelly RI, Pearse R, Bull RH, Leveque J-L, de Rigal J, Mortimer PS. The effects of aging on the cutaneous microvasculature. Journal of the American Academy of Dermatology. 1995;33(5):749-56. DOI: 10.1016/0190-9622(95)91812-4

View at: Publisher Site: https://www.jaad.org/ article/0190-9622(95)91812-4/fulltext

PubMed: https://pubmed.ncbi.nlm.nih.gov/7593773/

Europe PMC: https://europepmc.org/article/ $\mathrm{med} / 7593773$

6. Ahsanuddin S, Lam M, Baron ED. Skin aging and oxidative stress. 2016. AIMS Molecular Science. 2016; 3(2):187-195. DOI: 10.3934/molsci.2016.2.187 View at: Publisher Site: http://www.aimspress.com/ article/10.3934/molsci.2016.2.187

7. Sroka J, Madeja Z. [Reactive oxygen species in regulation of cell migration. The role of thioredoxin reductase]. Postepy biochemii. 2009;55(2):145-52. [in Polish]

View at: PubMed: https://pubmed.ncbi.nlm.nih. gov/19824470/

8. Masaki H. Role of antioxidants in the skin: anti-aging effects. Journal of dermatological science. 2010;58(2):8590. doi: 10.1016/j.jdermsci.2010.03.003

View at: Publisher Site: https://www.jdsjournal.com/ article/S0923-1811(10)00078-2/fulltext

PubMed: https://pubmed.ncbi.nlm.nih.gov/20399614/ Europe PMC: https://europepmc.org/article/ $\mathrm{med} / 20399614$

9. Matés JM, Sánchez-Jiménez F. Antioxidant enzymes and their implications in pathophysiologic processes. Frontiers in bioscience: a journal and virtual library. 1999;4(4):0339-345. DOI: 10.2741/mates

View at: PubMed: https://pubmed.ncbi.nlm.nih. gov/10077544/

10. Chelikani P, Fita I, Loewen PC. Diversity of structures and properties among catalases. Cellular and Molecular Life Sciences CMLS. 2004;61(2):192-208. DOI: 10.1007/s00018-003-3206-5

View at: Publisher Site: https://link.springer.com/ article/10.1007\%2Fs00018-003-3206-5

PubMed: https://pubmed.ncbi.nlm.nih.gov/14745498/ Europe PMC: http://europepmc.org/article/ $\mathrm{MED} / 14745498$

11. Balsano C, Alisi A. Antioxidant effects of natural bioactive compounds. Current pharmaceutical design. 2009;15(26):3063-73. DOI: 
10.2174/138161209789058084

View at: Publisher Site: https://www.eurekaselect. com/69944/article

PubMed: https://pubmed.ncbi.nlm.nih.gov/19754380/

12. Yasui K, Baba A. Therapeutic potential of superoxide dismutase (SOD) for resolution of inflammation. Inflammation Research. 2006;55(9):359-63. DOI: 10.1007/s00011-006-5195-y

View at: Publisher Site: https://link.springer.com/ article/10.1007\%2Fs00011-006-5195-y

PubMed: https://pubmed.ncbi.nlm.nih.gov/17122956/ Europe PMC: http://europepmc.org/article/ MED/17122956

13. Corvo ML, Jorge JC, van't Hof R, Cruz MEM, Crommelin DJ, Storm G. Superoxide dismutase entrapped in long-circulating liposomes: formulation design and therapeutic activity in rat adjuvant arthritis. Biochimica et Biophysica Acta (BBA)-Biomembranes. 2002;1564(1):227-36. DOI: 10.1016/ s0005-2736(02)00457-1

View at: Publisher Site: https://www.sciencedirect.com/ science/article/pii/S0005273602004571?via\%3Dihub PubMed: https://pubmed.ncbi.nlm.nih.gov/12101017/ Europe PMC: http://europepmc.org/article/ med/12101017

14. Akitomo Y, Akamatsu H, Okano Y, Masaki H, Horio T. Effects of UV irradiation on the sebaceous gland and sebum secretion in hamsters. Journal of dermatological science. 2003;31(2):151-9. DOI: 10.1016/ s0923-1811(03)00003-3

View at: Publisher Site: https://www.jdsjournal.com/ article/S0923-1811(03)00003-3/fulltext

PubMed: https://pubmed.ncbi.nlm.nih.gov/12670726/ Europe PMC: https://europepmc.org/article/ $\mathrm{med} / 12670726$

15. Faidati W, Barakbah J. Penilaian status antioksidan total pada penderita kusta di unit rawat jalan penyakit kulit dan kelamin RSUD Dr. Soetomo Surabaya. MDVI. 2001;28(SII):209S-14S.

16. Fisher GJ, Wang Z, Datta SC, Varani J, Kang S, Voorhees JJ. Pathophysiology of premature skin aging induced by ultraviolet light. New England Journal of Medicine. 1997;337(20):1419-29. DOI: 10.1056/ NEJM199711133372003

View at: Publisher Site: https://www.nejm.org/doi/ full/10.1056/nejm199711133372003

PubMed: https://pubmed.ncbi.nlm.nih.gov/9358139/

17. Birkedal-Hansen H, Moore W, Bodden M, Windsor L, Birkedal-Hansen B, DeCarlo A, et al. Matrix metalloproteinases: a review. Critical Reviews in Oral Biology \& Medicine. 1993;4(2):197-250. doi: 10.1177/10454411930040020401

View at: Publisher Site: https://journals.sagepub.com/ doi/abs/10.1177/10454411930040020401

Publisher Site pdf: https://journals.sagepub.com/doi/pd f/10.1177/10454411930040020401

PubMed: https://pubmed.ncbi.nlm.nih.gov/8435466/

18. Krutmann J, Bouloc A, Sore G, Bernard BA, Passe- ron $\mathrm{T}$. The skin aging exposome. Journal of dermatological science. 2017;85(3):152-61. DOI: 10.1016/j. jdermsci.2016.09.015

View at: Publisher Site: https://www.jdsjournal.com/ article/S0923-1811(16)30816-7/fulltext

PubMed: https://pubmed.ncbi.nlm.nih.gov/27720464/ Scopus: https://www.sciencedirect.com/science/article/ pii/S0923181116308167

19. Oikarinen A. Aging of the skin connective tissue: how to measure the biochemical and mechanical properties of aging dermis. Photodermatology, photoimmunology \& photomedicine. 1994;10(2):47-52.

View at: PubMed: https://pubmed.ncbi.nlm.nih. gov/8043384/

Semantic Scholar: https://www.semanticscholar.org/paper/Aging-of-the-skin-connective-tissue\%3A-how-to-measure-Oikarinen/43b90f22899ad869b5728e36715914da21434a50

20. Guinot C, J-M Malvy D, Ambroisine L, Latreille J, Mauger E, Tenenhaus M, et al. Relative Contribution of Intrinsic vs Extrinsic Factors to Skin Aging as Determined by a Validated Skin Age Score. Archives of dermatology. 2002;138:1454-60. DOI: 10.1001/ archderm.138.11.1454.

View at: Publisher Site: https://jamanetwork.com/ journals/jamadermatology/article-abstract/479070

PubMed: https://pubmed.ncbi.nlm.nih.gov/12437451/

21. Draelos ZK. Cosmetics in Dermatology: Churchill Livingstone. Edinburgh, 1995.

22. Watson RE, Gibbs NK, Griffiths CE, Sherratt MJ. Damage to skin extracellular matrix induced by UV exposure. Antioxidants \& redox signaling. 2014;21(7):106377. DOI: 10.1089 /ars.2013.5653

View at: Publisher Site: https://www.liebertpub.com/ doi/10.1089/ars.2013.5653

PubMed: https://pubmed.ncbi.nlm.nih.gov/24124905/

Europe PMC: https://europepmc.org/article/ $\mathrm{med} / 24124905$

23. Chung JH. Photoaging in Asians. Photodermatology, Photoimmunology \& Photomedicine. 2003;19(3):10921. doi: 10.1034/j.1600-0781.2003.00027.x.

View at: Publisher Site: https://onlinelibrary.wiley.com/ doi/full/10.1034/j.1600-0781.2003.00027.x

PubMed: https://pubmed.ncbi.nlm.nih.gov/12914595/ Scopus: https://snucm.elsevierpure.com/en/ publications/photoaging-in-asians

Europe PMC: https://europepmc.org/article/ $\mathrm{med} / 12914595$

24. Petropoulos I, Conconi M, Wang X, Hoenel B, Brégégère Fo, Milner $\mathrm{Y}$, et al. Increase of oxidatively modified protein is associated with a decrease of proteasome activity and content in aging epidermal cells. The Journals of Gerontology Series A: Biological Sciences and Medical Sciences. 2000;55(05):B220-B7. doi: 10.1093/gerona/55.5.b220

View at: Publisher Site: https://academic.oup.com/ biomedgerontology/article/55/05/B220/2948112 PubMed: https://pubmed.ncbi.nlm.nih.gov/10819308/ 
25. Kohen R, Nyska A. Invited review: Oxidation of biological systems: oxidative stress phenomena, antioxidants, redox reactions, and methods for their quantification. Toxicologic pathology. 2002;30(6):620-50. doi: 10.1080/01926230290166724

View at: Publisher Site: https://journals.sagepub.com/ doi/10.1080/01926230290166724

PubMed: https://pubmed.ncbi.nlm.nih.gov/12512863/

Europe PMC: https://europepmc.org/article/ $\mathrm{med} / 12512863$

26. Toussaint O, Medrano E, Von Zglinicki T. Cellular and molecular mechanisms of stress-induced premature senescence (SIPS) of human diploid fibroblasts and melanocytes. Experimental gerontology. 2000;35(8):927-45. DOI: $10.1016 / \mathrm{s} 0531-5565(00) 00180-7$

View at: Scopus: https://www.sciencedirect.com/science/ article/abs/pii/S0531556500001807?via\%3Dihub PubMed: https://pubmed.ncbi.nlm.nih.gov/11121681/

27. Swindells K, Rhodes L. Influence of oral antioxidants on ultraviolet radiation-induced skin damage in humans. Photodermatology, photoimmunology \& photomedicine. 2004;20(6):297-304. DOI: 10.1111/j.1600-0781.2004.00121.X

View at: Publisher Site: https://onlinelibrary.wiley.com/ doi/abs/10.1111/j.1600-0781.2004.00121.x

PubMed: https://pubmed.ncbi.nlm.nih.gov/15533237/

28. Fisher GJ, Quan T, Purohit T, Shao Y, Cho MK, He T, et al. Collagen fragmentation promotes oxidative stress and elevates matrix metalloproteinase- 1 in fibroblasts in aged human skin. The American journal of pathology. 2009;174(1):101-14. DOI: 10.2353/ajpath.2009.080599 View at: Publisher Site: https://ajp.amjpathol.org/ article/S0002-9440(10)61269-2/fulltext

PubMed: https://pubmed.ncbi.nlm.nih.gov/19116368/ PubMed Central: https://www.ncbi.nlm.nih.gov/pmc/ articles/PMC2631323/

29. Fisher GJ, Voorhees JJ, editors. Molecular mechanisms of photoaging and its prevention by retinoic acid: ultraviolet irradiation induces MAP kinase signal transduction cascades that induce Ap-1-regulated matrix metalloproteinases that degrade human skin in vivo. Journal of Investigative Dermatology Symposium Proceedings; 1998: Elsevier.

View at: Publisher Site: https://core.ac.uk/download/ pdf/82734732.pdf

PubMed: https://pubmed.ncbi.nlm.nih.gov/9732061/

30. Fisher GJ, Datta SC, Talwar HS, Wang Z-Q, Varani J, Kang S, Voorhees JJ. Molecular basis of sun-induced premature skin ageing and retinoid antagonism. Nature. 1996;379(6563):335. DOI: 10.1038/379335a0.

View at: Publisher Site: https://www.nature.com/ articles $/ 379335 \mathrm{a} 0$

PubMed: https://pubmed.ncbi.nlm.nih.gov/8552187/

Europe PMC: https://europepmc.org/article/ $\mathrm{med} / 8552187$

31. Rocquet C, Bonté F. Molecular aspects of skin ageing: recent data. ACTA Dermatovenerologica alpina panonica et adriatica. 2002;11(3):71-94.
View at: Publisher Site: http://www.acta-apa.org/ journals/acta-dermatovenerol-apa/papers/10.15570/ archive/2002/3/Rocquet.pdf

ResearchGate: https://www.researchgate.net/publication/281894397_Molecular_aspects_of_skin_ageing Recent_data

32. Kangralkar V, Patil SD, Bandivadekar R. Oxidative stress and diabetes: a review. Int J Pharm Appl. 2010;1(1):38-45.

View at: Semantic Scholar: https://www.semanticscholar.org/paper/OXIDATIVE-STRESS-AND-DIABETES\%3 A-A-REVIEW-Kangralkar-Patil/307ad115a657548765f8ba540f8da6cef755872e

33. Miller A. Fe superoxide dismutase. In: Messerschmidt A, Huber R, Poulos T, Wieghart K, editors. Handbook of Metalloproteins. Chichester: John Wiley \&Sons; 2001. p. 668-82.

View at: Publisher Site: http://www.docme.su/ doc/1930200/edited-by-a.-messerschmidt--r.-huber-t.-poulos-and-k.-wi...

Onlinelibrary: https://onlinelibrary.wiley.com/doi/ abs/10.1002/aoc. 298

34. Hong-Duk Y, Eun-Ja K, Jung-Hye R, HAH YC, SaOuk K. A novel nickel-containing superoxide dismutase from Streptomyces spp. Biochemical Journal. 1996;318(3):889-96. DOI: 10.1042/bj3180889

View at: Publisher Site: https://portlandpress.com/biochemj/article-abstract/318/3/889/32962/A-novel-nickel-containing-superoxide-dismutase?redirectedFrom=fulltext

SemanticScholar: https://pdfs.semanticscholar.org/f45a/ e6a08be9c1bffee50c33244229e49e3e1772.pdf

35. İnal ME, Kanbak G, Sunal E. Antioxidant enzyme activities and malondialdehyde levels related to aging. Clinica Chimica Acta. 2001;305(1-2):75-80. doi: 10.1016/s0009-8981(00)00422-8.

View at: Scopus: https://www.sciencedirect.com/science/ article/abs/pii/S0009898100004228?via\%3Dihub PubMed: https://pubmed.ncbi.nlm.nih.gov/11249925/ Europe PMC: https://europepmc.org/article/ $\mathrm{med} / 11249925$

36. Younus H. Therapeutic potentials of superoxide dismutase. Int J Health Sci (Qassim). 2018;12(3):88-93.

View at: PubMed: https://pubmed.ncbi.nlm.nih. gov/29896077/

PubMed Central: https:/www.ncbi.nlm.nih.gov/pmc/ articles/PMC5969776/

37. Bafana A, Dutt S, Kumar A, Kumar S, Ahuja PS. The basic and applied aspects of superoxide dismutase. Journal of Molecular Catalysis B: Enzymatic. 2011;68(2):12938. DOI: $10.1016 /$ j.molcatb.2010.11.007

View at: Scopus: https://www.sciencedirect.com/science/ article/abs/pii/S1381117710002900?via\%3Dihub

38. Takahashi H, Hashimoto Y, Aoki N, Kinouchi M, Ishida-Yamamoto A, Iizuka H. Copper, zinc-superoxide dismutase protects from ultraviolet B-induced apoptosis of SV40-transformed human keratinocytes: the protection is associated with the increased 
levels of antioxidant enzymes. Journal of dermatological science. 2000;23(1):12-21. DOI: 10.1016/ s0923-1811(99)00060-2

View at: Publisher Site: https://www.jdsjournal.com/ article/S0923-1811(99)00060-2/fulltext

PubMed: https://pubmed.ncbi.nlm.nih.gov/10699760/

39. Filipe P, Emerit I, Vassy J, Rigaut J, Martin E, Freitas J, et al. Epidermal localization and protective effects of topically applied superoxide dismutase. Experimental dermatology. 1997;6(3):116-21. DOI: 10.1111/j.16000625.1997.tb00157.x

View at: Publisher Site: https://onlinelibrary.wiley.com/ doi/abs/10.1111/j.1600-0625.1997.tb00157.x

PubMed: https://pubmed.ncbi.nlm.nih.gov/9226133/

40. Poljšak B, Dahmane R. Free radicals and extrinsic skin aging. Dermatology research and practice. 2012;2012. DOI: $10.1155 / 2012 / 135206$

View at: Publisher Site: https://www.hindawi.com/ journals/drp/2012/135206/

PubMed: https://pubmed.ncbi.nlm.nih.gov/22505880/ PubMed Central: https://www.ncbi.nlm.nih.gov/pmc/ articles/PMC3299230/

41. Urbanska M, Nowak G, Florek E. [Cigarette smoking and its influence on skin aging]. Przeglad lekarski. 2012;69(10):1111-4. [in Polish]

View at: https://pubmed.ncbi.nlm.nih.gov /23421102/\#: :text=Cigarette\%20smoke\%20causes $\% 20$ unfavorable $\% 20$ skin, smoking $\% 2070 \% 20$ year $\% 20$ old $\% 20$ adults.

Europe PMC: https://europepmc.org/article/ $\operatorname{med} / 23421102$

42. Yin L, Morita A, Tsuji T. Alterations of extracellular matrix induced by tobacco smoke extract. Arch Dermatol Res. 2000;292(4):188-94. doi: 10.1007/s004030050476 View at: Scopus: https://link.springer.com/ article/10.1007/s004030050476

PubMed: https://pubmed.ncbi.nlm.nih.gov/10836612/ Europe PMC: https://europepmc.org/article/ $\mathrm{med} / 10836612$

43. Miyachi Y. The cumulative effect of continual oxidative stress to the skin and cutaneous aging. Cutaneous aging. 1988:435-47.

44. Jackson S. Skin as an organ of protection. In: Dermatology in general medicine. 1993;1:241-53.

View at: https://accessmedicine.mhmedical.com/Content.aspx? bookId $=392$ \&sectionId $=41138745$

https://w w w a mazon.com/Dermatology-General-Medicine-Thomas-Fitzpatrick/ dp/0070212074

45. Ghadially R, Brown BE, Sequeira-Martin SM, Feingold KR, Elias PM. The aged epidermal permeability barrier. Structural, functional, and lipid biochemical abnor- malities in humans and a senescent murine model. The Journal of clinical investigation. 1995;95(5):2281-90. DOI: $10.1172 /$ JCI117919.

View at: Publisher Site: https://www.jci.org/articles/ view/117919

PubMed: https://pubmed.ncbi.nlm.nih.gov/7738193/

PubMed Central: https://www.ncbi.nlm.nih.gov/pmc/ articles/PMC295841/

Europe PMC: https://europepmc.org/article/ med/11913735

46. Wang YN, Fang H, Wang HM, Chen HC. [Effect of chronic exposure to ultraviolet on skin barrier function]. Zhejiang Da Xue Xue Bao Yi Xue Ban = Journal of Zhejiang University Medical sciences. 2010;39(5):51722. [in Chinese]

View at: PubMed: https://pubmed.ncbi.nlm.nih. gov/20936728/

Europe PMC: https://europepmc.org/article/ $\operatorname{med} / 20936728$

47. Di Cerbo A, Laurino C, Palmieri B, Iannitti T. A dietary supplement improves facial photoaging and skin sebum, hydration and tonicity modulating serum fibronectin, neutrophil elastase 2 , hyaluronic acid and carbonylated proteins. Journal of Photochemistry and Photobiology B: Biology. 2015;144:94-103. doi: 10.1016/j.jphotobiol.2014.12.025

View at: Publisher Site: https://www.sciencedirect.com/ science/article/pii/S101113441400390X?via\%3Dihub PubMed: https://pubmed.ncbi.nlm.nih.gov/25732262/

48. Tokudome Y, Takahashi Y. Antioxidants Inhibit Subsequent Lipid Production via Sebaceous Gland Cell Differentiation. J Dermat Cosmetol. 2017;1(3):00015. DOI: $10.15406 /$ jdc.2017.01.00015

View at: Publisher Site: https://medcraveonline.com/ JDC/antioxidants-inhibit-subsequent-lipid-production-via-sebaceous-gland-cell-differentiation.html

49. García-González A, Herrera-Abarca J, Ochoa JL. Effect of superoxide dismutase from bovine erythrocytes on different activity parameters in adjuvant-induced arthritis. Archives of medical research. 1999;30(2):132-7. doi: 10.1016/s0188-0128(98)00025-6.

View at: Publisher Site: https://www.sciencedirect.com/ science/article/pii/S0188012898000256?via\%3Dihub PubMed: https://pubmed.ncbi.nlm.nih.gov/10372448/ Europe PMC: https://europepmc.org/article/ $\operatorname{med} / 10372448$

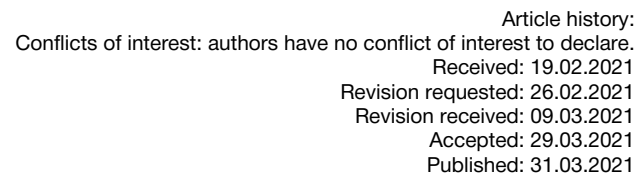




\title{
ЕФЕКТИВНІСТЬ ПРИЙОМУ ПЕРОРАЛЬНОЇ СУПЕРОКСИДДИСМУТАЗИ (СОД) НА ЗАГАЛЬНИЙ АНТИОКСИДАНТНИЙ СТАТУС (ЗАС), ТРАНСЕПІДЕРМАЛЬНУ ВТРАТУ ВОДИ (ТЕВВ) I КОНЦЕНТРАЦІЮ СЕКРЕТУ САЛЬНИХ ЗАЛОЗ У ФОТОСТАРІЮЧІЙ ШКІРІ
}

\author{
Хайруддин Джавад, Деві Ангграіні \\ Медичний факультет, Університет Хасануддін, Макассар, Індонезія \\ duddindjawad@gmail.com
}

\begin{abstract}
Актуальність. Старіння - це прогресуючий процес зниження функцій і можливостей органів, в тому числі шкіри. Фотостаріння - це зовнішнє старіння, яке в основному відбувається через вплив ультрафіолету (УФ). Ефективність перорального прийому антиоксиданту супероксиддисмутази (СОД) при передчасному старінні (або фотостарінні) на сьогоднішній день не відома.

Мета: оцінити ефективність прийому СОД для загального антиоксидантного статусу (ЗАС), гідратації шкіри (ТЕВВ) і концентрації шкірного сала при передчасному фотостарінні шкіри.

Методи. Це дослідження $є$ науковим проектом клінічного дослідження з однією групою досліджуваних, яких тестували до- і після УФ-опромінення. Всі досліджувані піддавалися УФ-опромінення протягом приблизно 3-4 годин. Всі досліджувані підписали інформовану згоду і пройшли відповідну співбесіду. Фотостаріння діагностувалося в клінічному аспекті трьома дерматологами відповідно до класифікації по Глогув тип II. Зокрема, оцінювалися динамічні зморшки, пальпуємий кератоз, видимі старечі пігментні плями і мімічна складка. СОД $250 \mathrm{MO}$ давали всім досліджуваним два рази на день протягом 60 днів. Лабораторні дослідження ЗАС, ТЕВВ і концентрації секрету сальних залоз проводилися до і після впливу УФ.

Результати. У дослідження було включено 25 осіб з типом шкіри 4 по Фітцпатріку. Серед них були 14 чоловіків і 11 жінок, 20 осіб у віці 30-40 років і 5 осіб у віці 25-29 років. Чотирнадцять (56\%) з 18 досліджуваних із групи з низьким ЗАС мали нормальний ЗАС після прийому СОД. Тест МакНемара показав значне збільшення значення ЗАС до і після прийому СОД ( $<<0,05$ ). Вимірювання ТЕВВ в області щоки показало, що 9 з 10 досліджуваних з «strained» групи мали нормальне значення ТЕВВ після прийому СОД, в той час як всі 3 досліджуваних з «critical» групи мали нормальне значення ТЕВВ. Вимірювання ТЕВВ в області чола показало, що у 7 досліджуваних з «strained» групи TEBB мав нормальне значення. Себуметрія в області чола показала, що з 17 досліджуваних, з групи із сухою шкірою, 14 (56\%) - мали нормальну шкіру, 1 (4\%) - жирну, а у 2 - шкіра залишалася сухою після прийому СОД протягом 60 днів. Себуметрія в області щоки показала, що у всіх досліджуваних, з групи із сухою шкірою, шкіра ставала нормальною після прийому СОД.
\end{abstract}

Висновок. Після прийому СОД протягом 60 днів значно збільшилося значення ЗАС, зменшилася ТЕВВ і покращилося вологоутримання шкіри

Ключові слова: супероксиддисмутаза (СОД), загальний антиоксидантний статус (ЗАС), трансепідермальна втрата води (ТЕВВ), секрет сальних залоз

\section{ЭФФЕКТИВНОСТЬ ПРИЕМА ПЕРОРАЛЬНОЙ СУПЕРОКСИДДИСМУТАЗЫ (СОД) НА ОБЩИЙ АНТИОКСИДАНТНЫЙ СТАТУС (ОАС), ТРАНСЭПИДЕРМАЛЬНУЮ ПОТЕРЮ ВОДЫ (ТЭПВ) И КОНЦЕНТРАЦИЮ СЕКРЕТА САЛЬНЫХ ЖЕЛЕЗ В ФОТОСТАРЕЮЩЕЙ КОЖЕ}

\author{
Хайрудоин Джавад, Деви Ангграини \\ Медииинский факультет, Университет Хасануддина, Макассар, Индонезия \\ duddindjawad@gmail.com
}

\begin{abstract}
Актуальность. Старение - это прогрессирующий процесс снижения функций и возможностей органов, в том числе кожи. Фотостарение - это внешнее старение, которое в основном происходит из-за воздействия ультрафиолета (УФ). Эффективность перорального приема антиоксиданта супероксиддисмутазы (СОД) при преждевременном старении (или фотостарении) на сегодняшний день не известна.

Цель: оценить эффективность приема СОД для общего антиоксидантного статуса (OAC), гидратации кожи (ТЭПВ) и концентрации кожного сала при преждевременном фотостарении кожи.

Методы. Это исследование представляет собой научный проект клинического исследования с одной группой испытуемых, которых тестировали до и после УФ-облучения. Все испытуемые подвергались УФ-облучению в течение примерно 3-4 часов. Все испытуемые подписали информированное согласие и прошли соответствующее собеседование. Фотостарение диагностировалось в клиническом аспекте тремя дерматологами в соответствии с классификацией по Глогув тип II. В частности, оценивались динамические морщины, пальпируемый кератоз, видимые старческие пигментные пятна и мимическая складка. СОД $250 \mathrm{ME}$ давали всем испытуемым два раза в день в течение 60 дней. Лабораторные исследования ОАС, ТЭПВ и концентрации секрета сальных желез проводились до и после воздействия УФ.

Результаты. В исследование было включено 25 человек с типом кожи 4 по Фитцпатрику. Среди них были 14 мужчин и 11 женщин, 20 человек в возрасте 30-40 лет и 5 человек в возрасте 25-29 лет. Четырнадцать (56\%) из 18 испытуемых из группы с низким ОАС имели нормальный ОАС после приема СОД. Тест МакНемара показал значительное увеличение значения ОАС до и после приема СОД ( $<0.05)$. Измерение ТЭПВ в области щеки показало, что 9 из 10 испытуемых из «strained» группы имели нормальное значение ТЭПВ после приема СОД, в то время как все 3 испытуемых из «critical» группы имели нормальное значе-
\end{abstract}


ние ТЭПВ. Измерение ТЭПВ в области лба показало, что у 7 испытуемых из «strained» группы ТЭПВ имел нормальное значение. Себуметрия в области лба показала, что из 17 испытуемых, из группы с сухой кожей, 14 (56\%) - имели нормальную кожу, 1 (4\%) - жирную, а у 2 - кожа оставалась сухой после приема СОД в течение 60 дней. Себуметрия в области щеки показала, что у всех испытуемых, из группы с сухой кожей, кожа становилась нормальной после приема СОД.

Вывод. После приема СОД в течение 60 дней значительно увеличилось значение ОАС, уменьшилась ТЭПВ и улучшилось влагосодержание кожи

Ключевые слова: супероксиддисмутаза (СОД), общий антиоксидантный статус (ОАС), трансэпидермальная потеря воды (ТЭПВ), секрет сальных желез 